\title{
Mapping the nexus of transitional justice and peacebuilding
}

\author{
Catherine Baker and Jelena Obradovic-Wochnik
}

\begin{abstract}
This paper explores the convergences and divergence between transitional justice and peacebuilding, by considering some of the recent developments in scholarship and practice. We examine the notion of 'peace' in transitional justice and the idea of 'justice' in peacebuilding. We highlight that transitional justice and peacebuilding often engage with similar or related ideas, though the scholarship on in each field has developed, largely, in parallel to each other, and often without any significant engagement between the fields of inquiry. We also note that both fields share other commonalities, insofar as they often neglect questions of capital (political, social, economic) and at times, gender. We suggest that trying to locate the nexus in the first place draws attention to where peace and justice have actually got to be produced in order for there not to be conflict and violence. This in turn demonstrates that locally, 'peace' and 'justice' do not always look like the 'peace' and 'justice' drawn up by international donors and peacebuilders; and, despite the 'turn to the local' in international relations, it is surprising just how many local and everyday dynamics are (dis)missed as sources of peace and justice, or potential avenues of addressing the past.
\end{abstract}

\section{Introduction}

This special issue examines the relationships between transitional justice and peacebuilding, and locates and illustrates the nexus between these practices and literatures. Both transitional justice and peacebuilding are discourses and practices of intervention aimed at (post)violent societies: transitional justice is intended as a set of mechanisms aimed at confronting and dealing with human rights abuses and atrocities, whilst peacebuilding is more wide-ranging, but often aimed at strengthening institutions as a means of preventing further violence. Both inform and are bound up with each other, particularly, as this volume shows, through intervention practices of external donors.

The contributions in this special issue set out and examine a number of puzzles resulting from the peacebuilding-transitional justice relationship: they identify how and why transitional justice and peacebuilding came to embody the goals that they do; how the international actors' focus on statecentric responses to post-conflict contexts, and the normative drive of transitional justice towards 'peace' and 'justice', ignores a wide range of issues that not only exist under the radar of international intervention and scholarship but risk creating new grievances. By interrogating the nexus of transitional justice and peacebuilding, this special issue finds that 'peripheral' means of addressing violent pasts (Sharp 2013b), such as socioeconomic justice or the everyday practices of normality and sociability though religion or local economies, remain marginalised by both transitional justice and peacebuilding.

Some of the practical and conceptual challenges of the peacebuilding-transitional justice convergence, are illustrated by an early example of a landmark transitional justice mechanism - the International Criminal Tribunal for the former Yugoslavia (ICTY). When the ICTY was set up in 1993, it worked to a mandate of 'bring[ing] to justice those responsible for serious violations of international humanitarian law' and 'thus contribut[ing] to the restoration and maintenance of peace in the region' (ICTY n.d.). The ICTY, one of the few war crimes tribunals in existence, was envisaged both as a tool of transitional justice and peacebuilding. This was a vague and near impossible target for a single institution to achieve, and such a mandate points to the opaqueness of both concepts, as used and often applied by key institutions and actors. The court's mandate raised key debates which continue today, and which form a significant proportion of transitional justice literature: what is the relationship between post-conflict justice and peace?

Further, what is the relationship between transitional justice and peacebuilding? The idea that one will lead to the other is often the underlying logic of external intervention, even though it is not always clear how the two practices ought to shape each other. The ICTY is just one example of this: when the former Yugoslav states failed to comply with the court's indictments, compliance was linked directly to EU membership conditionality (itself seen as a crucial tool for building lasting peace). As 
Sharp (2013b) notes, around this time, transitional justice emerged out of the peripheries of international politics and became mainstream. The hope amongst international actors intervening in post-conflict spaces, was that transitional justice would help remove perpetrators from the political life, and that the recognition of victims would lead to less grievance in the future, thus preventing another cycle of conflict. However, as this special issue discusses, the relationship between transitional justice and peacebuilding is not only contentious and non-linear, but often, also neglected by scholars of both fields. Transitional justice and peacebuilding are deeply intertwined, both practically and discursively, but the amount of literature connecting these two scholarships and practices is relatively low. Even though Rama Mani called attention to 'the nexus between rebuilding peace and restoring justice' as early as 2002 (Mani 2002: 4), the overlaps between the two fields have been neglected. Furthermore, as Sharp (2013a:195 notes, 'remarkably' similar critiques have been raised against both transitional justice and peacebuilding, even though these fields have 'historically proceeded on separate tracks'. These observations are some of the starting points of discussions raised by this special issue.

This introduction first outlines the key literature in both fields, locating 'peace' in transitional justice and 'transitional justice' in peacebuilding, before discussing the implications and outlining the contributions of the papers in this volume.

\section{Where is peace in transitional justice?}

'Peacebuilding' and 'transitional justice', like any other analytical concepts, exist because institutions and scholars have constructed them as objects that can be known about. They are named in publication titles that present themselves as contributing to the understanding of one topic or the other; in journal and series titles that ascribe a publication the authority of having been recognised as contributing to such a thing; in the titles of institutes and degree programmes that train new aspirants to practising in the fields they denote. Both are analytical categories imposed on the complexity of post-conflict societies and interventions, socially constructed through labelling and citation (see Berger and Luckmann 1966; Hart 1998).

The work that citation does in not just reflecting but producing understandings of what knowledge is seen as authoritative within a discipline is illustrated both by reviews of individual fields - such as Christine Bell's argument that the 'narration of the field of transitional justice as interdisciplinary' represents a specific move in the struggle over what the goals of transitional justice should be (Bell 2009: 24 ) - and more broadly, as in recent bibliometric studies of gendered citation practices in International Relations that observe a perceptible 'citation gap' (Maliniak, Powers and Walter 2013) where women's scholarship is cited less than men's, potentially to women's detriment in academic career progression (Mitchell, Lange and Brus 2013). Intervening in a field's politics of knowledge to alter its boundaries or challenge where the most authority is thought to rest therefore takes what Sara Ahmed (2014b: 15) describes as 'willful citational practice' - a tool she views as essential for unmaking the gendered and racialised hierarchies of authority in research (Ahmed 2014a).

Comparing and combining the insights of peacebuilding and transitional justice research thus begins with understanding what questions have been emphasised and why in either field. Chandra Lekha Sriram, for instance, begins her foundational article on transitional justice and critiques of liberal peacebuilding by observing that critical peacebuilding research had problematized the notions of 'marketisation and democratisation' on which liberal peacebuilding depends but had not extended into 'the unexamined assumptions and potential unintended consequences that transitional justice shares with peacebuilding', which then became the focus of her argument (Sriram 2007: 582). Dustin Sharp, building on Sriram by synthesising peacebuilding and transitional justice critiques, similarly urged scholars to "call into question the reasons for the historic privileging of certain items over others' and 'examine what this emphasis might say about transitional justice as a political project' (Sharp 2013b: 157). Thus, while a few scholars such as Sriram, Sharp, or Wendy Lambourne (2009) build their interpretive framework by drawing together both fields, the concepts are otherwise joined less often than their simultaneous mobilization in post-conflict interventions suggests that they might be. There is, as Gearoid Millar and Jesse Lecy suggest in their contribution to this issue, a shortage of publications that actively seek to 
build bridges between the two fields, which scholars through their citational practices have produced as separate literatures, or that (going beyond drawing on one field to refresh another) aim to exchange theories, findings and practices holistically between the fields.

Within transitional justice literature, however, the concepts of peacebuilding and transitional justice have been brought together for some time in weighing up the 'peace versus justice debate'. This question of how far investigating, prosecuting and punishing war crimes might frustrate efforts to obtain a peace settlement or make a return to violence more likely originated in 1994-95 as the United Nations began setting up the International Criminal Tribunal for the Former Yugoslavia (ICTY) while the conflict in Bosnia-Herzegovina (BiH) was still ongoing (D'Amato 1994; Akhavan 1996, 1998; Anonymous 1996; Gaer 1997). Articles testing this proposition once the Dayton Peace Agreement for BiH had starting to be implemented argued for the UN to prioritise 'peace over justice' (Bratt 1997), framed it as a question of 'peace versus justice?' (Schuett 1997), or argued that the European Union had followed a route to 'peace through justice' (Kerr 2007) in expecting post-Yugoslav accession candidates to cooperate with the ICTY. Martha Minow contrasted the poles of 'vengeance and forgiveness' (retributive justice on one hand, and social reconciliation on the other) in her study of how societies had responded to genocide and mass violence in the 20th century (Minow 2000). Notions of peace and justice continue to provide framing juxtapositions in transitional justice research: there was scope (perhaps) for 'achieving peace with justice' in Uganda (Keller 2008); 'balancing peace and justice' was the dilemma in demobilising Colombia's paramilitaries (Arvelo 2006); 'peace versus justice?' was the problem that Sriram and Suren Pillay posed readers of their edited volume on transitional justice in Africa (Sriram and Pillay ed. 2011). Indeed, the two could probably be related to each other through every conceivable pronoun.

The peace versus justice debate, however, placed transitional justice and peacebuilding less into a nexus and more as competing meteorological fronts which, through their conflicting objectives and likely outcomes, threatened to tear the overall goal of post-conflict transformation apart. For authors such as Payam Akhavan, writing on 'the so-called "peace versus justice" debate' (Akhavan 2009: 625), or David Tolbert (2009), a former deputy chief prosecutor at the ICTY, the peace versus justice problem primarily concerned political and military leaders who might be disincentivised from making peace if they were indicted for war crimes or who might demand impunity from prosecution before they would agree to make peace. What had been an ad hoc problem when the ICTY was set up during an ongoing military conflict in the mid-1990s became a permanent feature of the international judicial and diplomatic system after 2002 when the statute establishing the International Criminal Court came into force. The ICC's investigations in Uganda and Darfur offered examples where the pursuit of cases against leaders who would still need to be involved in an effective peace settlement, such as the Sudanese president Omar al-Bashir, supposedly made indicted leaders less likely to seek peace (see Oette 2010).

The potential clashes between creating accountability for crimes and violence through transitional justice processes and laying solid foundations for peace did not, moreover, occur solely on the level of leadership, but resonated throughout civil society and the public sphere as societal obstacles to postconflict transformation - indeed could even be matters for ' global civil society' (Glasius 2009: 497, our emphasis), on which the international legitimacy of transitional justice institutions would depend. Research on the public reception of the ICTY in post-Yugoslav states - a social context which must be acknowledged to extend into post-Yugoslav diasporas around the world (Halilovich 2013) - depicts discursive fields in which the politicisation of international criminal justice appears to exacerbate, rather than reconcile, clashes of collective narratives about guilt and victimhood during the Yugoslav wars. From a starting point that views reconciliation as 'the restoration and repair of relationships and as the acknowledgement of war crimes and responsibility', for instance, Janine Natalya Clark (2009: 360) concluded that the ICTY's findings were much more likely to be instrumentalised in support of narratives that hardened inter-ethnic boundaries - especially in support of denials of responsibility for mass violence and genocide - to contribute to members of the public transforming their understanding of what had taken place, and they would therefore work against rather than encourage the reconciliation that would need to occur in order for there to be anything other than a 'negative peace'.

Public reactions to the ICTY illustrated how deeply, and quickly, it became embedded into the politics of competing ethnicised collective narratives about guilt and victimhood during (and before) the Yugoslav wars. Ethnopoliticised narratives about the ICTY would simultaneously accuse it of bias against the speaker's own ethnonational group while expecting the tribunal to produce an authoritative 
narrative of the past and then be disappointed when it did not (Bieber 2014; Nielsen 2014). An inherent feature of most judicial institutions, the capacity for a verdict to be reversed on appeal, would transform into a sudden intervention in ethnicised memory politics when ICTY findings of guilt against symbolic figures (such as Ante Gotovina, the Croatian Army general whose indictment had taken in the 'Oluja' offensive that ended the Croatian war of independence in August 1995, or Momčilo Perišić, chief of the general staff of the Army of Yugoslavia between June 1992 and November 1998) were reversed and memory politics based on how the ICTY had narrated the conflict up until now had to be reconfigured (Clark 2013; Subotić 2014).

These polemics were themselves, however, a symptom of how collective ethnopolitical narratives about the wars had been allowed to dominate the public sphere at the expense of any other frames for understanding them (Gordy 2013; Obradović-Wochnik 2013). Scholars' and activists' rationales for recommending non-judicial transitional justice processes such as a pan-ex-Yugoslav truth and reconciliation commission (the Regional Commission or RECOM) suggested that creating more space for alternative accounts would strengthen peace by undermining the hegemony of post-war ethnopolitics (Simić and Volčič ed. 2013). The approaches to conceptualising justice that emerge from studies of the post-Yugoslav cases start to demonstrate both the diversity of how justice may be understood (as Lai 2016, Hronesova 2016 and O'Reilly 2016, show in this issue) and the shift from 'peace versus justice' to a concept that 'there can be no peace without justice' that Clark (2011: 539) suggests came to characterise peacebuilding interventions through and after the establishment of conflict resolution mechanisms for Rwanda and Bosnia-Herzegovina.

\section{Where is transitional justice in peacebuilding?}

Recognising justice as an inherently contested concept in itself offers a pathway for connecting transitional justice to peacebuilding: the struggles over meanings, hierarchies and resources that could be revealed by identifying competing visions of justice in the post-Yugoslav cases or any other are among the very struggles with which peacebuilding practitioners and researchers also contend in understanding how peace might be reached after conflict and why peacebuilding initiatives so often fail. In making their case for 'the value of participation and local agency' in transitional justice processes - bringing to bear interpretive frameworks from development studies - Patricia Lundy and Mark McGovern (2008: 265-6) asked 'Whose justice?'. ${ }^{1}$ Lundy and McGovern's answer was that it should be justice as viewed by local communities, not however justice might have perceived by a post-conflict government, foreign donors or the UN. They suggested that unofficial 'bottom-up "truth-telling" process[es]' like their own object of study, the Ardoyne Commemoration Project in Northern Ireland, were the most effective, since, here, local people's participation in all stages of the project brought them into direct contact with other community members in a space where they had to resolve troublesome issues of how to remember the conflict (Lundy and McGovern 2008: 290-1).

Rosemary Nagy (2008: 279-80), similarly questions 'the categories of when, to whom and for what transitional justice applies', arguing that tribunals and truth commissions conceive of responsibility in ways that leave pre/post-conflict 'continuities of violence and exclusion', structural forms of violence, and external actors out of the accounts they produce. The marginalisation of gendered injustice that feminist scholars of transitional justice have perceived in most judicial and non-judicial justice mechanisms is a fundamental illustration of 'who' and 'what' is often missing (Bell and O'Rourke 2007; Ní Aoláin 2009, 2012). Even when justice mechanisms have taken sufficient account of gender politics to recognise that, for instance, sexual violence should be tried as a war crime (an international legislative innovation in the ICTY statute), they could not be said to have met survivors' wider need for justice if, as Katherine Franke suggests, witnesses require 'the public telling of their stories and a sense that they are being heard' before they can feel that they have justice but 'this kind of truth-telling is not within the jurisdiction of formal legal fora' (Franke 2006: 818).

Acknowledgement of multiple forms of justice has become the hinge for several transitional justice scholars to engage directly with the precepts of peacebuilding. Clark, for instance, seeks to resolve the peace and justice debate by emphasising that 'justice entails far more than retribution' (Clark 2011:

\footnotetext{
${ }^{1}$ See also Rama Mani's framing of 'the nexus between transitional justice and development' (Mani 2008: 253).
} 
521) and that restorative justice, the aim of civil-society-led participatory public education projects she praises in Rwanda and Serbia, has greater potential in post-conflict reconciliation (Clark 2008) - yet if restoration entails 'a return to a set of relationships that $[. .$.$] may have been fundamentally unjust', as$ Bell and O'Rourke (2007: 41) argue would frequently be the case for women, even restorative justice would not be sufficient. One peacebuilding/justice nexus that does not depend on 'dualistic' oppositions of 'peace versus human rights' or 'retributive versus restorative justice' (Lambourne 2009: 48) emerges in the work of Wendy Lambourne, who uses 'the multiple meanings of justice and reconciliation' (2004: 9) as her analytical lens for critiquing peacebuilding initiatives that in her view had not been designed around recognition and redress of survivors' psychosocial needs - which would themselves vary according to context. Lambourne instead proposed a model of 'transformative justice' comprising 'accountability, or legal justice; "truth", or knowledge and acknowledgement; socioeconomic justice; and political justice' (Lambourne 2009: 37). Ensuring justice 'in the present and future' through meeting this goals would produce 'sustainable peacebuilding' for the long term (Lambourne 2009: 45).

Equivalent arguments that take a multidimensional approach to justice, identify injustices that flow from each dimension, and use these as the basis for proposing transformative models of peacebuilding can be found inside and outside the field-specific literature. Rama Mani, who called attention to 'the nexus between rebuilding peace and restoring justice' as early as 2002 (Mani 2002: 4), argues that 'legal', 'rectificatory' (that is, setting right the 'direct human consequences of conflict') and 'distributive' forms of justice all need to be achieved in order to prevent conflict, and that when peacebuilding fails it is often because the more structural injustices have not been addressed (Mani 2002: 5-6). Her own vision for post-conflict peacebuilding would be based on a 'reparative justice' as the precondition for creating an '“inclusive' political and civic community', no longer categorised by collective 'divisions of winners versus losers, victims versus perpetrators, "us" and "them"" (Mani 2005: 512). Kora Andrieu (2010: 543-4) uses Mani's re-envisioning of transitional justice as reparative justice as the basis for critiquing the teleological logic of peacebuilding and democratisation. Nancy Fraser's formulation of 'redistribution, recognition and representation' (Fraser 2008: 6) as three dimensions of justice, with corresponding injustices that can be identified and named as a result, is the basis for a contribution to a much wider field of social and cultural theory but creates a similar analytic to Lambourne's or Mani's that scholars of transitional justice and peacebuilding have been able to apply (see Lai 2016; Hronesova 2016 and O’Reilly 2016.

The nexus between peacebuilding and transitional justice emerges, however, not only from the 'justice' but also the 'transition'. Transition is a contested concept itself, both in certain post-conflict societies and in the field as a whole. The term has had specific connotations in various settings, such as the discourses of 'transition to democracy' in post-authoritarian Chile and Argentina (Arthur 2009: 336), or the post-socialist as well as post-conflict meanings of the term 'transition' in post-Yugoslav societies, where the framework of 'transition' from state socialism to democracy and the free market became a discourse explaining the narrowing-down of life chances that economic liberalisation on the back of wartime destruction had brought about (Jansen 2006; Majstorović 2007). Beyond the resonances of 'transition' in an individual context, moreover, discourses of transition in any setting imply assumptions about "what the transition is "from" and "to"" which often go unvoiced but need to be critically examined (Bell and O'Rourke 2007: 35): the 'to' and 'from' themselves are likely to be matters of political contestation over how the post-conflict system will be structured and where power will lie.

Nevertheless, as a project of reshaping political, social and economic institutions to produce the conditions for peace - however that peace may be understood - peacebuilding presupposes the alteration of what had existed before and, thus, transition; even if this linear script is appropriate, it is so commonly deployed that it becomes part of what there is to analyse. Indeed, one criticism of transitional justice theorising from a peacebuilding perspective in Cillian McGrattan's polemic with Kris Brown over transitional justice in Northern Ireland was that it fails to "examine the political framework of the "transition" (McGrattan 2009: 168; see also Brown 2010; McGrattan 2010). Justice for peacebuilding scholars would be one aspect, but one aspect only, of the transformations with which they are concerned. The 'peace via justice' premise, key to the UN's rationale for establishing war crimes tribunals for the former Yugoslavia and Rwanda (Clark 2011: 539), would fit justice squarely under the umbrella of 'any and all elements identified by local and international stakeholders as attempts to create, strengthen and solidify peace' (Autesserre 2014: 21) which, together, constitute the framework of 
peacebuilding. With such an institutional linkage, which was being produced at the very time that peacebuilding and transitional justice were emerging as fields of research, one might wonder why they should even have ended up as separate fields rather than distinct but interlinked topics of inquiry within a unified field of studying post-conflict reconstruction. As it is, however, locating the nexus between transitional justice and peacebuilding often requires reading two fields in parallel and extracting what can materialise, within the two communities of practice, as strikingly similar lenses and debates.

\section{Peacebuilding's 'local turn' and consequences for transitional justice}

The literatures on peacebuilding and transitional justice tend to resemble 'parallel' tracks rather than one integrated field (Sharp 2013a: 165), with scholars who position themselves in either field still being unlikely to draw in the literature that has constituted the other field on equal terms with the literature that has constituted their own (see also Millar and Lecy, 2016). Nevertheless, as Dustin Sharp noted when mapping a direction for linking both fields in 2013 (Sharp 2013a, 2013b), the critical study of peacebuilding deals with similar problems to those raised by transitional justice researchers who have sought to question what 'justice' might consist of, whose interests it meets and who is or should be responsible for bringing it about. The significance of 'the local' and 'the international', the power relationships in which these scales of activity are embedded, and the deconstruction of both these domains are key concepts in peacebuilding research, which shows peacebuilding as well as transitional justice to be embedded into international structures in comparable ways. ${ }^{2}$

The 'turns' through which peacebuilding studies have gone in the 2000s and 2010s as peacebuilding practices have themselves evolved share a concern with scale, asymmetry and power which is also visible in critical studies of 'top-down' transitional justice. Critiques of the 'liberal peace' as an ineffective, inappropriate or outright neo-imperialist form of Western power projection in the name of peacebuilding (Pugh 2005; Chandler 2006; Cooper 2007; Richmond 2009b; Jabri 2012) echo the reaction against 'top-down' transitional justice mechanisms that characterises much critical literature on the ICTY, the ICTR and the International Criminal Court. Alternative models that are intended to be more participatory and accountable and that centre the local level as a site of capacity and agency in peacebuilding - whatever 'the local' actually consists of (Mac Ginty 2015) - are argued for along the same lines as the 'bottom-up' models of transitional justice recommended by authors such as Lundy and McGovern. Indeed, one recent literature review of the 'local turn' in peacebuilding included Lundy and McGovern's research on transitional justice within a set of studies examining local agency in peacebuilding (others in this section were on youth masculinities, local peace committees and local zones of peace) (Leonardsson and Rudd 2015: 832); transitional justice is here just one of the many dimensions that peacebuilding involves. So well-established in peacebuilding studies is the 'local turn' that it now has its own critical literature interrogating how the local is constituted, stratified, mobilised and (de)politicised in theory and policy (Richmond 2009c; Heathershaw 2012; Mac Ginty and Richmond 2013; Hughes, Öjendal and Schierenbeck 2015; Kappler 2015; Paffenholz 2015).

Rethinking the local-international relationship in peacebuilding has led to the recognition of 'hybrid forms of peace' (Mac Ginty 2011; Richmond and Mitchell ed. 2012) as the consequence of liberal peace agents' and local actors' interactions with each other, and another emerging line of practice and scholarship that has been termed the 'hybrid turn' (Mac Ginty and Richmond, in press). Transitional justice recognises one aspect of this context in the institution of the 'mixed tribunal' or 'hybrid court', which (as in Timor Leste or Kosovo) hears war crimes cases with a combination of local and foreign judges (Dickinson 2003; Martin-Ortega and Herman 2012). Dustin Sharp (2013a: 170), indeed, notes the emergence of 'more hybridized forms of peacebuilding and transitional justice', using 'a mixture of conventional and local practices and models', in his work bridging the two fields (though whose conventions are these, why would the local automatically be seen as unconventional, and what if some people within 'the local' want a more 'conventional' peace than some foreign interveners?).

One analytic for understanding hybridity in peacebuilding and for conceptualising a so-called postliberal peace, the focus on 'the everyday' as a means of making local agency visible and meaningful

\footnotetext{
${ }^{2}$ See Sharp 2013a: 183-5, which summarises these in the interests of building linkages between transitional justice and peacebuilding (a conceptual project discussed further below).
} 
(Richmond 2009a, 2009b; Mitchell 2011; Mac Ginty 2013, 2014), has opened another seam of research that parallels, and shares the normative assumptions of, critical transitional justice studies that emphasise the bottom-up. Extending this agenda into the everyday practices of peacebuilding itself through ethnographic research has enabled peacebuilding researchers to highlight the micropolitics of power, space and knowledge that are constitutive, in this perspective, of how interventions operate and how peace might (not) be built (Pouligny 2006; Higate and Henry 2009; Autesserre 2014; Baker 2014). This lens has not been turned on transitional justice mechanisms to the same extent but is one of several ways in which drawing together the fields of transitional justice and peacebuilding may create new possibilities for understanding the aftermath of conflict.

\section{Observing the nexus of transitional justice and peacebuilding}

Although the study of transitional justice and peacebuilding has followed parallel yet often detached tracks, in the practice of conflict management and conflict resolution the division between them is not always so clear. Peacebuilding practice may often involve activities usually labelled transitional justice, such as support for or the funding of criminal tribunals or truth commissions. For instance, the US Agency for International Development (USAID) often funds peacebuilding projects such as those aimed at strengthening institutions in post-conflict countries, and is also supporting 'truth-seeking initiatives' in Cambodia, Colombia, Cote d'Ivoire and Guatemala (USAID 2015). The Colombian peace and transitional justice process is also supported by 'traditional' peacebuilding agencies, the UN and World Bank, as well as Germany (ICTJ 2015). The EU, which has a long-standing commitment to peacebuilding through its Common Security and Defence Policy (CSDP), integration and other policies, sees transitional justice as integral to many of its peacebuilding efforts, and has thus supported (financially and politically) initiatives such as the International Criminal Court (ICC) (Davis 2014).

Indeed, Kora Andrieu (2010: 538) argues that transitional justice 'has become an essential part of any liberal peacebuilding operation'. Perceptions of justice, and contestation over how justice should be understood, are among the factors that condition how a peacebuilding intervention develops (Hyden 2015). Moreover, the doctrines, narratives and practices of certain key peacebuilding actors that have committed themselves to post-conflict reconstruction in the image of the 'liberal peace' often view transitional justice as the very path to building the long-term peace they seek. The UN Secretary-General's 2004 report on 'Rule of Law and Transitional Justice in Post-Conflict Societies', for instance, exemplified for Sriram (2007: 585) the integration of transitional justice and peacebuilding that had been forged in international post-conflict reconstruction practice in the early 2000s. Rachel Kerr perceived a 'symbiotic relationship between peace and justice' (2007: 373) in the EU's attitude to postYugoslav states in the 2000s, when it made milestones in their stabilization and accession negotiations conditional on co-operation with the ICTY. Simultaneously, however, 'difficult choices' about postconflict governance that might fix the parameters of how the 'transition' to be achieved through justice might unfold - for instance decisions about the national judicial system or security-sector reform - may have been taken, in a de facto way, by 'international peacekeeping and peacebuilding actors, ranging from the United Nations to bilateral donors' at quite an early stage of intervention (Sriram 2004: 3).

The legacies of ad hoc initial decisions and competing agencies' priorities in peacebuilding show that the process is by no means linear nor straightforward. Often evident, however, are top-down practices through which the narratives and strategies of international actors (such as those of a powerful donor government or the EU) filter down to peacebuilding on the ground through donations and funding for specific projects. For instance, one of the key grassroots mechanisms of transitional justice in the former Yugoslavia is a campaign for a truth commission, led by a coalition of NGOs. Despite this being a grassroots organisation, much of the discourse about the past is donor-driven and reflects the concerns of 'peace', 'justice' and 'reconciliation' found amongst its key donors' (e.g. European Commission) concerns.

The empirically discernible overlaps and relationships between transitional justice and peacebuilding are indeed starting to become the subject of an emergent literature, with connections drawn through the work of scholars such as Sriram, Lambourne, Mani and Sharp. Chandra Lekha Sriram's work is central to the nexus here in applying critiques of liberal peacebuilding to transitional justice and arguing that both mechanisms when externally imposed are likely to have destabilizing effects (Sriram 2007). 
Kris Brown (2010: 123) maps out a number of themes, from norm diffusion to national identity formation and (again) the critique of the liberal peace, that peacebuilding and International Relations scholars might use transitional justice to explore. Karin Aggestam and Annika Björkdahl, examining the Western Balkans and the Middle East, ask what achieving a 'just peace' might involve (Aggestam and Björkdahl ed. 2013). Dustin Sharp (2013b: 151), like Sriram, notes that transitional justice is 'increasingly associated' with 'narrow transitions to democracy' and peacebuilding and is often 'yet another box to tick on the "post-conflict checklist". He goes on to identify a socioeconomic dimension to the liberal peace, so closely associated with 'transitions to liberal market democracy' as well as top-down institutional capacity-building (Sharp 2013b: 152), leading to questions of socioeconomic (in)justice in liberal market transitions which the peacebuilding and transitional justice literatures have often, though not always (Mani 2002; Pugh 2005; Miller 2008; Pugh, Cooper and Turner ed. 2008; Waldorf 2012; Jennings and Bøås 2015), ignored. The erasure of 'structural colonial violence' from and through transitional justice - which Sarah Maddison and Laura Shepherd (2014) make visible by applying insights from critical peacebuilding studies - runs even deeper.

\section{The production and circulation of knowledge in peacebuilding and transitional justice}

A key set of questions informing the recognition of this nexus is therefore how knowledge of transitional justice or peacebuilding is circulated, and how discourses about what these concepts and institutions should mean or do are reproduced, contested and reconfigured as the processes of peacebuilding and transitional justice take effect. How and why, for instance, have the values and goals of 'peace', 'justice' and 'reconciliation' (as opposed to any other sets of values) been attached to and made the key aims of what is generally understood as 'transitional justice'? The anthropologist Stef Jansen (2013), explaining contested notions of justice in Bosnia-Herzegovina, asks 'If reconciliation is the answer, are we asking the right questions?' in arguing that peacebuilders' quest for 'reconciliation' has depoliticized Bosnian society. These questions can be asked for any transitional justice/peacebuilding intervention. For instance, critical peacebuilding debates about agency, local knowledge and the everyday make it possible to perceive the structural implications that occur when local justice practices which may have had similar goals to 'transitional justice' projects but pre-dated the arrival of international peacebuilding efforts have been overlooked or dismissed as strategies for achieving 'transitional justice', in favour of other imported mechanisms, once internationally-driven processes of peacebuilding take hold (see Lamont 2016; Martin 2016).

Indeed, even the nature of what may become known as transitional justice or as peace being built is often the result of what individual groups and actors are able to negotiate, either with local governments or external funders (see O'Reilly 2016; Hronesova 2016). Care must, as a result, be taken to disaggregate the normative goals of transitional justice - peace, reconciliation, justice, truth. These are concepts with an intellectual history and a developmental trajectory; that is, it must be remembered that they are not 'natural' nor a given, and that their interpretation not only varies between socio-cultural contexts but their meanings will always be contested even amongst seemingly coherent groups, such as survivors (Lambourne 2009: 46; Ní Aoláin 2012: 206). Indeed, the very act of framing a contestation as a struggle between abstract concepts may itself be a political move, as Kimberley Armstrong argues in a study of the ICC's investigation of the conflict between the Ugandan government and the Lord's Resistance Army: in Armstrong's view, the discursive constructions of 'peace' and 'justice' used by Ugandan political and media actors were in fact mobilized to legitimize their own particular claims to authority over the process of conflict resolution in northern Uganda (Armstrong 2014: 592).

Yet the concepts of truth, justice, peace and reconciliation are often de facto starting-points, rather than constructs for analysis, in transitional justice analyses asking why these have not yet been achieved (at least compared to the amount of weight given in the peacebuilding literature to interrogating the concept of peace). The papers in this issue, conversely, ask: what are the different ways in which peace, justice, truth and reconciliation are understood? When and how do they converge and diverge? How do constructs and normative ideas about truth and justice result in specific international and local practices? Raising these questions as they draw together the insights of transitional justice and peacebuilding research, they suggest that in particular that both literatures have missed the full significance of key postconflict dynamics of socio-economic inequality. 


\section{The question of capital in transitional justice and peacebuilding}

Socio-economic issues are, as research in this issue confirms, a crucial injustice felt by the people who constitute 'the local' in transitional justice contexts. As mechanisms and processes, however, both transitional justice and peacebuilding tend to ignore the question of capital - economic, social, and political - while transitional justice's focus on truth and justice often leaves no room to examine the less tangible ways in which populations and communities feel affected by conflicts (Miller 2008; Lambourne 2009: 34). As Sharp (2013b: 149) notes, the 'historically dominant liberal' paradigm of transitional justice has narrowed responses to violence to such an extent that it has marginalised questions of 'economic violence and economic justice'. Transitional justice often creates mechanisms that seek to help only those directly affected by violence: individuals and families of the killed and disappeared; survivors of sexualized violence during war; refugees; and the most obviously and directly involved perpetrators. Peacebuilding practice, meanwhile, has placed a much stronger focus on rebuilding democratic institutions (as a route to peace) than on individuals, as critiques of the liberal peace emphasise. Both approaches to post-conflict reconstruction have thus neglected more subtle forms of dispossession and victimhood. And yet, while income inequality, socioeconomic marginalisation and unemployment linked to the effects of conflict often affect even greater proportions of post-conflict societies (see Lai 2016), most mainstream international intervention approaches are almost completely un-equipped to deal with them, even though dynamics of inequality present the potential for conflict of all kinds. Resistance to dominant approaches of peacebuilding and transitional justice is seen clearly in episodes such as the Bosnian popular protests of 2014 (Arsenijević ed. 2015; Lai 2016) which not only surprised the international community but also highlighted the inadequacy of transitional justice and peacebuilding mechanisms (Hromadžić 2015).

Another form of inequality, the stratification of survivor/victim groups based on their unequal access to social and political capital, also influences how transitional justice and peacebuilding processes are shaped (Hronesova 2016, Lai 2016 and O'Reilly 2016, illustrate). As the authors in this volume show, international intervention and peacebuilding practices can inadvertently set up political systems in which victim and survivor groups must become efficient lobbyists and pander to local power games in order to achieve transitional justice goals such as reparations or specific laws. Transitional justice here reveals itself as not just subject to competing interpretations but as wholly dependent on a number of dynamics not originally envisaged as part of its normative aims, such as bargaining, negotiating, accessing capital, and engaging with local politics which are often - despite the frequent 'romanticisation' of the local in peacebuilding practice (Richmond 2009c) a site of illiberality or oppression (See Arnauld 2016; Lai 2016; Hronesova 2016).

'Truth' and 'reconciliation' thus do not occur largely as a result of international pressure or local goodwill, but within a complex political economy of transitional justice and peacebuilding. Indeed, what becomes known or implemented as transitional justice or the building of peace is deeply affected by capital; the flow of capital from donors (such as the EU and USAID) to conflict-affected regions can be traced, and with it the flow of discourse and frameworks for what kinds of knowledge are even valid (Sampson 1996; Autesserre 2014). Competitive bidding between local NGOs for external funding means that what transitional justice initiatives become implemented are dependent on who gets which grant; in turn, the funded initiatives become visible and leaders of these projects become spokespersons for 'local transitional justice', obscuring less tangible local engagement with the past (Martin 2016). Moreover, many of these, sometimes invisible, local processes of facing the past have their roots in religious practice (see Martin 2016; Lamont 2016). Yet the global narrative or 'global project' (Nagy 2008) which drives transitional justice practice and peacebuilding, and which is deeply underscored by ideas of the liberal peace, often overlooks the religious as a possible site of confronting the past (not least since religious ideologies are often seen as the cause of many post-Cold War conflicts) (Clark 2010).

Locating the nexus between peacebuilding and transitional justice thus involves, firstly, seeking out empirical and conceptual ways in which they have overlapped. How for instance are they conceived as distinct, how not, and how did the empirically observable nexus between them come about? Secondly, and equally importantly, it involves building a common critical agenda from the questions each field of research has sought to ask. Whom, for instance, are each of these sets of institutions and practices for, and whom could they be for outside the understandings of peace, justice and reconstruction that are 
currently hegemonic? What notions of peace and justice are in play in any post-conflict setting, and how is the power to determine and implement their meaning an object of struggle in a given case? What knowledges would not fit even into this compartmentalisation of the aftermath of conflict? What inequalities are or might be strengthened, created or undone as the peacebuilding-transitional justice nexus is pursued? Continuing the work of connecting these two fields can, this issue suggests, offer more effective means of envisaging not just transition but even transformation.

\section{Illustrating the nexus: what can be done now?}

The papers in this special issue are the result of a British International Studies Association-sponsored workshop, held on 15 June 2015, in which the presenters were asked to explore the convergences and divergences between transitional justice and peacebuilding. The idea for this workshop arose out of a long-standing discussion between the special issue editors, who had noticed that - as the bibliometrics of Millar and Lecy (2016) would corroborate - scholarship on transitional justice and critical peacebuilding often engage with the same questions of power, accountability and scale but not necessarily with the other field's literature. Further, the idea of 'the local' and 'the everyday' has become a key concern in both peacebuilding literature and practice just as transitional justice scholarship has explored the 'bottom-up'; yet at the same time, as Sharp (2013b: 157) notes, the practice of transitional justice continues to privilege 'the state and the individual rather than the community and the group; the legal and technocratic rather than the political and contextual; and international rules and standards rather than cultural norms and local practices'.

This issue therefore urges researchers of peacebuilding, transitional justice and other post-conflict societies towards a more holistic conceptualization of such processes by illustrating how the nexus between transitional justice and peacebuilding can become a productive analytical tool.

Millar and Lecy (2016), consider what bibliometrics and citations can tell us about the development of transitional justice and peacebuilding literature. A number of important insights emerge from this paper, but one of the most significant findings is that much transitional justice and peacebuilding literature is self-referential, with very few works actively bridging the gap between the two. This would suggest that both literatures developed in a sort of echo-chamber, with scholars talking amongst themselves within their own group. This certainly is not unusual, and illustrates the ways in which the majority of social sciences literatures function, but the surprising issue here is that both literatures often deal with the same problems but do not seem to actively engage each other. The further implication is thus that one of the reasons why specific meanings have been attached to transitional justice and peacebuilding, both in terms of scholarship and practice, has been this relatively closed discussion, and the often-introspective look to established or foundational literature (e.g. Orentlicher 1991 and Lederdach 1997). This raises important questions: if transitional justice has developed along specific lines and has adopted particular meanings, partly as a lack of an external discussion, how then, has this shaped practice, and our own interpretations of what transitional justice is all about?

Arnauld's paper illustrates shows clearly how interpretative frames conditions international and domestic actors' positions on transitional justice practice, and implicitly, shows us the consequences of the self-referential debate sketched out by Millar and Lecy (2016). Arnauld, focusing on the Democratic Republic of Congo (DRC), moves the debate beyond the 'local vs. external' tensions, which are so often highlighted in both transitional justice and peacebuilding, and discusses how both international and domestic actors can variously act as resisters or promoters of transitional justice. The important finding here is that contestation does not exclusively arise out of rejection of internationally imposed transitional justice mechanisms, but can also be due to the competing interpretations of what transitional justice is for. This finding has a broader implication for the peacebuilding/transitional justice nexus: Arnauld finds that international actors' narrow focus on statebuidling (primarily through strengthening institutions as a way of peacebuilding), contributed significantly to the failure of transitional justice in the DRC

The implication that international actors engaged in peacebuilding in post-conflict contexts, and their focus on institutions, often help build systems which are not always conducive to transitional justice, is also demonstrated by other authors in this volume: Hronesova (2016), Lai (2016) and Lamont (2016). Focusing on Bosnia, Hronesova (2016) connects peacebuilding and transitional justice literature 
by discussing how the international efforts to peacebuild in Bosnia, inadvertently created political systems in which only the most vocal groups of survivors (especially those aligning themselves along 'ethnic' lines and pandering to party politics), manage to access decision makers and benefit from their manipulation of the local system of governance (one originally mandated by the international community).

This dynamic is resonant in Lamont's (2016) paper, too, where he discusses how the international community mandated a state-centric vision of transitional justice, in a context in which the state was highly contested. Lamont argues that the internationally-mandated statebuilding in Libya, based on the liberal peacebuilding notion of the transition to democracy and a market-based economy, disempowered voices that did not privilege the state. Resonating Arnauld's (2016) findings on resistance to transitional justice, in this volume, Lamont also suggests that local resistance to transitional justice may not always be countering transitional justice as such, but an attempt to advance alternative political orders. In other words, what might look like local resistance to transitional justice, may simultaneously be a reaction against the narrow vision of peacebuilding. Importantly, the paper argues that the Libyan case highlights the need to rethink transitional justice intervention in the contexts of weak or contested states - states which, as Risse (2011) argues, are the rule, rather than an exception, in the global state system.

The ways in which international peacebuilding involvement poses further challenges to transitional justice, is highlighted by Lai, whose paper discusses how both peacebuilding and transitional justice neglect two major issues related to post-war contexts: poverty, and unequal distribution of capital, often compounded by elite-level corruption, lack of development and investment in key infrastructure and employability. Lai discusses how a popular social movement in Bosnia, campaigning for social justice, caught the international community and local leaders by surprise, to the point that neither was able to respond effectively to the protestors' demands. Importantly, both Lai and Hronesova show that international peacebuilding efforts often create systems in which marginalise the key groups that have justice demands. In other words, political systems that arise out of peacebuilding efforts and their focus on institutions, inadvertently privilege those with social, political or economic capital, that is, those who are able to navigate its structures and hierarchies, by playing the correct game (in the Bosnian context, one navigates the system and rises to the top by being 'ethnic', as this is what a significant proportion of internationally-mandated legislation and institutions are based on). The implication of this is that those who have justice demands but cannot navigate the system, either have to acquire capital and adapt to the game (as demonstrated by Hronesova) or are marginalised from the transitional justice process altogether (as demonstrated by Lai). This struggle - between the global vision of transitional justice with its norms of peace, justice and reconciliation, as developed through scholarship outlined by Millar and Lecy (2016), and local post-conflict demands, which often revolve around the basic needs of economic security, demonstrates just how much of the post-conflict everyday mainstream transitional justice approaches and literature manage to obscure.

This dynamic is also picked up by two subsequent paper by Martin, which, echoing Lamont (2016), highlights how local practices of justice and the return to 'normal' are invisible or dismissed by international transitional justice projects. Martin highlights an important dynamic, suggesting that transitional justice often focuses on the extraordinary - war, conflict, violence - and the mechanisms set up for dealing with the past often ask people to revisit these episodes, which sometimes lie outside of their everyday experiences. Focusing on Sierra Leone, Martin suggests that communities affected by violence, often have a need to return to 'normal' (or at least, what becomes the 'new normal') and often, to the everyday routine or even banal activities, instead of engaging with transitional justice initiatives that are anything but routine and 'normal'. Martin's findings show how communities in Sierra Leone use everyday farming and religious practices, to find their own means of re-establishing a 'normal' and thus deal with violent pasts. These routine activities, Martin argues, are unrecognised by transitional justice and peacebuilding as tools of coping. One reason for this might be the political economy of donor relationships within which most transitional justice initiatives function and are diffused, and which have to show tangible returns and outputs for donor capital. Banal, everyday activities do not fit these types of frameworks of 'confronting the past'. The danger of ignoring 'the unrecognised' or the informal practices that help restore 'normality', is that, as Martin finds, this also risks ignoring the knowledge and social networks that have existed before and during periods of violence, and which become the source of informal means of dealing with the past. 
Finally, O'Reilly adds another dimension to the often narrow approach to transitional justice, prescribed by and located in peacebuilding interventions. Focusing once more on Bosnia, O'Reilly discussed how despite the broadening of traditional justice and the adoption of UN Security Council Resolution 1325 on greater inclusion of women in security and post-conflict processes, transitional justice mechanisms often reinforce gender-based exclusions. Further, as the author notes, despite the critical turn in peacebuilding literature, the notion of gendered agency is often ignored. O'Reilly uses the example of the Women's Court in Bosnia, to reflect on the nature of exclusions and inclusions in postconflict justice processes, noting that the vision of peace and justice, as viewed by women, is often missing from transitional justice and peacebuilding initiatives.

Overall, this special issue goes some way to answering Sharp's challenge of recovering a 'deeper politics of transitional justice', but also peacebuilding, and interrogating their 'lingering peripheries' (Sharp 2013b: 157). This challenge does not involve 'suddenly privileging' the previously marginalised issues, but 'call into question the reasons for the historic privileging of certain items over others', and to 'examine what this emphasis might say about transitional justice as a political project' (Sharp 2013b: 157). We do this by interrogating the peripheries, many of which are the result or an unintended consequence of peacebuilding projects and interventions: socioeconomic justice, local projects ignored or dismissed as 'transitional justice', the attempts to reestablish the 'normal' after conflict, the religious, rural and gendered responses to formal justice, the impact of peacebuilding on local power relations, and the ways in which transitional justice projects can place war-affected groups into contexts where they must become lobbyists and bidders for their rights. We note that much of these dynamics are observed or embedded in peacebuilding contexts and theatres, thus the authors in this special issue also highlight the impact of transitional justice initiatives on peacebuilding projects and 'local' understandings of peace.

This special issue points to some key focal points for future transitional justice and peacebuilding research. Based on the findings presented by contributions to the volume, we suggest that trying to locate the nexus in the first place draws attention to where peace and justice have actually got to be produced in order for there not to be conflict and violence. This in turn demonstrates that locally, 'peace' and 'justice' do not always look like the 'peace' and 'justice' drawn up by international donors and peacebuilders; and, despite the 'turn to the local' in international relations, it is surprising just how many local and everyday dynamics are (dis)missed as sources of peace and justice, or potential avenues of addressing the past.

\section{References}

Aggestam, Karin, and Annika Björkdahl, ed. 2013. Rethinking Peacebuilding: the Quest for Just Peace in the Middle East and Western Balkans. London and New York: Routledge.

Ahmed, Sara. 2014a. "White Men." Feminist Killjoys, 4 November. Available at http://feministkilljoys.com/2014/11/04/white-men/ (accessed 13 November 2015).

Ahmed, Sara. 2014b. Willful Subjects. Durham, NC: Duke University Press.

Akhavan, Payam. 1996. "The Yugoslav Tribunal at a Crossroads: the Dayton Peace Agreement and Beyond.” Human Rights Quarterly 18 (2): 259-85.

Akhavan, Payam. 1998. "Justice in The Hague, Peace in the Former Yugoslavia?: a Commentary on the United Nations War Crimes Tribunal.” Human Rights Quarterly 4 (4): 737-816.

Akhavan, Payam. 2009. "Are International Criminal Tribunals a Disincentive to Peace?: Reconciling Judicial Romanticism with Political Realism.” Human Rights Quarterly 31 (3): 624-54.

Andrieu, Kora. 2010. "Civilizing Peacebuilding: Transitional Justice, Civil Society and the Liberal Paradigm.” Security Dialogue 41 (5): 537-58.

Anonymous. 1996. "Human Rights in Peace Negotiations." Human Rights Quarterly 18 (2): 249-58.

Armstrong, Kimberley. 2014. "Justice Without Peace?: International Justice and Conflict Resolution in Northern Uganda." Development and Change 45 (3): 589-607.

Arsenijević, Damir, ed. 2015. Unbribable Bosnia-Herzegovina: the Struggle for the Commons. BadenBaden: Nomos. 
Arthur, Paige. 2009. "How 'Transitions' Reshaped Human Rights: a Conceptual History of Transitional Justice." Human Rights Quarterly 31 (2): 321-67.

Arvelo, José E. 2006. "International Law and Conflict Resolution in Colombia: Balancing Peace and Justice in the Paramilitary Demobilization Process." Georgetown Journal of International Law 37: 41176.

Arnauld, Valerie. 2016. "Transitional Justice in Peacebuilding: Dynamics of Contestation in the Democratic Republic of Congo.” Journal of Intervention and Statebuilding 10 (3)

Autesserre, Séverine. 2014. Peaceland: Conflict Resolution and the Everyday Politics of International Intervention. Cambridge: Cambridge University Press.

Baker, Catherine. 2014. "The View from the Back of the Warrior: Mobility, Privilege and Power during the International Intervention in Bosnia-Herzegovina." In Mobilities in Socialist and Post-Socialist States: Societies on the Move, edited by Kathy Burrell and Kathrin Hörschelmann, 148-72. Basingstoke: Palgrave Macmillan.

Bell, Christine. 2009. "Transitional Justice, Interdisciplinarity and the State of the 'Field' or 'NonField'." International Journal of Transitional Justice 3 (1): 5-27.

Bell, Christine, and Catherine O'Rourke. 2007. "Does Feminism Need a Theory of Transitional Justice?: an Introductory Essay." International Journal of Transitional Justice 1 (1): 23-44.

Berger, Peter, and Thomas Luckmann. 1966. The Social Construction of Reality: a Treatise in the Sociology of Knowledge. London: Penguin.

Bieber, Florian. 2014. "Do Historians Need a Verdict?". In The Milošević Trial: an Autopsy, edited by Timothy William Waters, 349-55. London and New York: Routledge.

Bratt, Duane. 1997. "Peace over Justice: Developing a Framework for UN Peacekeeping Operations in Internal Conflicts." Global Governance 5: 63-81.

Brown, Kris. 2010. "Transitional Justice, Rigour and Politics: a Reply to McGrattan." Politics 30 (2): $119-24$.

Chandler, David. 2006. Empire in Denial: the Politics of State-Building. London: Pluto.

Clark, Janine Natalya. 2008. "The Three Rs: Retributive Justice, Restorative Justice, and Reconciliation." Contemporary Justice Review 11 (4): 331-50.

Clark, Janine Natalya. 2009. "From Negative to Positive Peace: the Case of Bosnia and Herzegovina." Journal of Human Rights 8 (4): 360-84.

Clark, Janine Natalya. 2010. "Religion and Reconciliation in Bosnia \& Herzegovina: Are Religious Actors Doing Enough?" Europe-Asia Studies 62 (4): 671-94.

Clark, Janine Natalya. 2011. "Peace, Justice and the International Criminal Court: Limitations and Possibilities." Journal of International Criminal Justice 9 (3): 521-45.

Clark, Janine Natalya. 2013. "Courting Controversy: the ICTY's Acquittal of Croatian

Generals Gotovina and Markač.” Journal of International Criminal Justice 11 (2): 399-423.

Cooper, Neil. 2007. "On the Crisis of the Liberal Peace." Conflict, Security and Development 7 (4): 605-16.

D’Amato, Anthony. 1994. "Peace vs. Accountability in Bosnia." American Journal of International Law 88 (3): 500-6.

Davis, Laura, 2014, The European Union and Transitional Justice, Civil Society Dialogue Network, Available at http://www.eplo.org/assets/files/2.\%20Activities/Civil\%20Society\%20Dialogue\%20Network/Policy\%20Meetings/Transitional\%20Justice/EPLO_CSDN_TJ_BackgroundDocument.pdf , Accessed 20 November 2015.

Dickinson, Laura A. 2003. "The Promise of Hybrid Courts.” American Journal of International Law 97 (2): 295-310.

Fraser, Nancy. 2008. Scales of Justice: Reimagining Political Space in a Globalizing World. New York: Columbia University Press.

Gaer, Felice D. 1997. "UN-Anonymous: Reflections on Human Rights in Peace Negotiations." Human Rights Quarterly 19 (1): 1-8.

Glasius, Marlies. 2009. "What is Global Justice and Who Decides?: Civil Society and Victim Responses to the International Criminal Court's First Investigations." Human Rights Quarterly 31 (2): 496-520.

Gordy, Eric D. 2013. Guilt, Responsibility, and Denial: the Past at Stake in Post-Milošević Serbia. Philadelphia, PA: University of Pennsylvania Press. 
Halilovich, Hariz. 2013. Places of Pain: Forced Displacement, Popular Memory and Trans-Local Identities in Bosnian War-Torn Communities. Oxford: Berghahn.

Hart, Chris. 1998. Doing a Literature Review: Releasing the Social Science Research Imagination. London: Sage.

Heathershaw, John. 2013. "Towards Better Theories of Peacebuilding: Beyond the Liberal Peace Debate." Peacebuilding 1 (2): 275-82.

Higate, Paul, and Marsha Henry. 2009. Insecure Spaces: Peacekeeping, Power and Performance in Haiti, Kosovo and Liberia. London: Zed.

Hromadžić, Azra. 2015. Citizens of an Empty Nation: Youth and State-Making in Postwar BosniaHerzegovina. Philadelphia, PA: University of Pennsylvania Press.

Hronesova, Jesse. 2016. "Might Makes Right: Compensatory War-Related Payments in Bosnia and Herzegovina" Journal of Intervention and Statebuilding 10 (3)

Hughes, Caroline, Joakim Öjendal and Isabel Schierenbeck. 2015. "The Struggle Versus the Song - the Local Turn in Peacebuilding: an Introduction." Third World Quarterly 36 (5): 817-24.

Hyden, Goran. 2015. "Rethinking Justice and Institutions in African Peacebuilding." Third World Quarterly 36 (5): 1007-22.

International Criminal Tribunal for the former Yugoslavia, n.d. Mandate and Crimes Under ICTY Jurisdiction, http://www.icty.org/en/about/tribunal/mandate-and-crimes-under-icty-jurisdiction Accessed 20 November 2015.

International Centre for Transitional Justice, ICTJ, 2015, UN, World Bank and Germany to Step up aid for Post-Conflict Colombia https://www.ictj.org/news/un-world-bank-and-germany-step-aid-post-conflict-colombia Published 17 February 2015, accessed 20 November 2015.

Jabri, Vivienne. 2012. The Postcolonial Subject: Claiming Politics/Governing Others in Late Modernity. London and New York: Routledge.

Jansen, Stef. 2006. "The Privatisation of Home and Hope: Return, Reforms and the Foreign Intervention in Bosnia-Herzegovina." Dialectical Anthropology 30 (3-4): 177-99.

Jansen, Stef. 2013. "If Reconciliation is the Answer, Are We Asking the Right Questions?" Studies in Social Justice 7 (2): 229-43.

Jennings, Kathleen M., and Mats Bøås. 2015. "Transactions and Interactions: Everyday Life in the Peacekeeping Economy." Journal of Intervention and Statebuilding 9 (3): 281-95.

Kappler, Stefanie. 2015. "The Dynamic Local: Delocalisation and (Re-)Localisation in the Search for Peacebuilding Identity." Third World Quarterly 36 (5): 875-89.

Keller, Linda M. 2008. "Achieving Peace with Justice: the International Criminal Court and Ugandan Alternative Justice Mechanisms." Connecticut Journal of International Law 23: 209-80.

Kerr, Rachel. 2007. "Peace Through Justice?: the International Criminal Tribunal for the Former Yugoslavia." Southeast European and Black Sea Studies 7 (3): 373-85.

Kerr, Rachel, and Eirin Mobekk. 2007. Peace and Justice: Seeking Accountability After War. Cambridge: Polity.

Lai, Daniela 2016. "Transitional justice and its discontents: socioeconomic justice in Bosnia and Herzegovina and the limits of international intervention" Journal of Intervention and Statebuilding 10 (3)

Lambourne, Wendy. 2004. "Post-Conflict Peacebuilding: Meeting Human Needs for Justice and Reconciliation." Peace, Conflict and Development 4: 1-24.

Lambourne, Wendy. 2009. "Transitional Justice and Peacebuilding after Mass Violence." International Journal of Transitional Justice 3 (1): 28-48.

Lamont, Chris K. 2016, "Contested Governance: Understanding Justice Interventions in Post-Qadhafi Libya" Journal of Intervention and Statebuilding 10 (3)

Leonardsson, Hanna, and Gustav Rudd. 2015. "The 'Local Turn' in Peacebuilding: a Literature Review of Effective and Emancipatory Local Peacebuilding.” Third World Quarterly 36 (5): 825-39.

Lundy, Patricia, and Mark McGovern. 2008. "Whose Justice? Rethinking Transitional Justice from the Bottom Up." Journal of Law and Society 35 (2): 265-92.

Mac Ginty, Roger. 2011. International Peacebuilding and Local Resistance: Hybrid Forms of Peace. Basingstoke: Palgrave Macmillan.

Mac Ginty, Roger. 2013. "Introduction: the Transcripts of Peace: Public. Hidden or Non-Obvious?" Journal of Intervention and Statebuilding 7 (4): 423-30. 
Mac Ginty, Roger. 2014. "Everyday Peace: Bottom-Up and Local Agency in Conflict-Affected Societies." Security Dialogue 45 (6): 548-64.

Mac Ginty, Roger. 2015. "Where is the Local?: Critical Localism and Peacebuilding." Third World Quarterly 36 (5): 840-56.

Mac Ginty, Roger, and Oliver P. Richmond. 2013. "The Local Turn in Peace Building: a Critical Agenda for Peace." Third World Quarterly 34 (5): 763-83.

Mac Ginty, Roger, and Oliver P. Richmond. In press. "The Fallacy of Constructing Hybrid Political Orders: a Reappraisal of the Hybrid Turn in Peacebuilding." International Peacekeeping. doi: 10.1080/13533312.2015.1099440.

Maddison, Sarah, and Laura J. Shepherd. 2014. "Peacebuilding and the Postcolonial Politics of Transitional Justice." Peacebuilding 2 (3): 253-69.

Majstorović, Danijela. 2007. "Construction of Europeanization in the High Representative's Discourse in Bosnia and Herzegovina." Discourse and Society 18 (5): 627-51.

Maliniak, Daniel, Ryan Powers, and Barbara F. Walter. 2013. "The Gender Citation Gap in International Relations." International Organization 67 (4): 889-922.

Mani, Rama. 2002. Beyond Retribution: Seeking Justice in the Shadows of War. Cambridge: Polity.

Mani, Rama. 2005. "Rebuilding an Inclusive Political Community after War." Security Dialogue 36 (4): 511-26.

Mani, Rama. 2008. "Dilemmas of Expanding Transitional Justice, or Forging the Nexus Between Transitional Justice and Development." International Journal of Transitional Justice 2 (3): 253-65.

Martin, Laura S., 2016, 'Practicing Normality: An Examination of Unrecognisable Mechanisms in Post-Conflict Sierra Leone' Journal of Intervention and Statebuilding 10 (3)

Martin-Ortega, Olga, and Johanna Herman. 2012. "Hybrid Tribunals: Interaction and Resistance in Bosnia and Herzegovina and Cambodia." In Hybrid Forms of Peace: from Everyday Agency to PostLiberalism, edited by Oliver P. Richmond and Audra Mitchell, 73-87. Basingstoke: Palgrave Macmillan.

McGrattan, Cillian. 2009. “'Order out of Chaos”: the Politics of Transitional Justice.” Politics 29 (3): 164-72.

McGrattan, Cillian. 2010. "The Politics of Transitional Justice or All's Well That Ends Well: a Reply to Brown." Politics 30 (2): 125-30.

Millar, Gearoid and Lecy, Jesse. 2016. "Disciplinary Divides in Post-Conflict Justice and Peace: Tracking If and How we Share Ideas" Journal of Intervention and Statebuilding 10 (3)

Miller, Zinaida. 2008. "Effects of Invisibility: in Search of the 'Economic' in Transitional Justice." International Journal of Transitional Justice 2 (3): 266-91.

Minow, Martha. 2000. Between Vengeance and Forgiveness: Facing History after Genocide and Mass Violence. Boston, MA: Beacon Press.

Mitchell, Audra. 2011. "Quality/Control: International Peace Interventions and 'the Everyday'." Review of International Studies 37 (4): 1623-45.

Mitchell, Sara McLaughlin, Samantha Lange, and Holly Brus. 2013. "Gendered Citation Patterns in International Relations Journals." International Studies Perspectives 14 (4): 485-92.

Nagy, Rosemary. 2008. "Transitional Justice as Global Project: Critical Reflections." Third World Quarterly 29 (2): 275-89.

Ní Aoláin, Fionnuala. 2009. "Women, Security, and the Patriarchy of Internationalized Transitional Justice." Human Rights Quarterly 31 (4): 1055-85.

Ní Aoláin, Fionnuala. 2012. "Advancing Feminist Positioning in the Field of Transitional Justice." International Journal of Transitional Justice 6 (2): 205-28.

Nielsen, Christian Axboe. 2014. "Can We Salvage a History of the Former Yugoslav Conflicts from the Milosevic Trial?”. In The Milošević Trial: an Autopsy, edited by Timothy William Waters, 326-48. London and New York: Routledge.

Obradovic-Wochnik, Jelena. 2013 Ethnic Conflict and War Crimes in the Balkans: Narratives of Denial in Post-Conflict Serbia London: IB Tauris

Oette, Lutz. 2010. "Peace and Justice, or Neither?: the Repercussions of the al-Bashir Case for International Criminal Justice in Africa and Beyond." Journal of International Criminal Justice 8 (2): 34564. 
O'Reilly, M. 2016, “Peace and Justice Through a Feminist Lens: Gender Justice and The Women's Court for the Former Yugoslavia" Journal of Intervention and Statebuilding 10 (3)

Paffenholz, Thania. 2015. "Unpacking the Local Turn in Peacebuilding: a Critical Assessment Towards an Agenda for Future Research.” Third World Quarterly 36 (5): 857-74.

Pouligny, Beatrice. 2006. Peace Operations Seen from Below: UN Missions and Local People. London: Hurst.

Pugh, Michael. 2005. "The Political Economy of Peacebuilding: a Critical Theory Perspective." International Journal of Peace Studies 10 (2): 23-42.

Pugh, Michael, Neil Cooper, and Mandy Turner, ed. 2008. Whose Peace?: Critical Perspectives on the Political Economy of Peacebuilding. Basingstoke: Palgrave Macmillan.

Richmond, Oliver P. 2009a. "Becoming Liberal, Unbecoming Liberalism: Liberal-Local Hybridity Via the Everyday as a Response to the Paradoxes of Liberal Peacebuilding." Journal of Intervention and Statebuilding 3 (3): 324-44.

Richmond, Oliver P. 2009b. "A Post-Liberal Peace: Eirenism and the Everyday." Review of International Studies 35 (3): 557-80.

Richmond, Oliver P. 2009c. "The Romanticisation of the Local: Welfare, Culture and Peacebuilding." The International Spectator 44 (1): 149-69.

Richmond, Oliver P., and Audra Mitchell, ed. 2012. Hybrid Forms of Peace: from Everyday Agency to Post-Liberalism. Basingstoke: Palgrave Macmillan.

Risse, T., ed., 2011, Governance without a State? Policies and Politics in Areas of Contested Statehood New York: Columbia University Press

Sampson, Steven. 1996. "The Social Life of Projects: Importing Civil Society to Albania." In Civil Society: Challenging Western Models, edited by C. M. Hann and Elizabeth Dunn, 121-42. London and New York: Routledge.

Schierenbeck, Isabel. 2015. "Beyond the Local Turn Divide: Lessons Learnt, Relearnt and Unlearnt." Third World Quarterly 36 (5): 1023-32.

Schuett, Oliver. 1997. "The International War Crimes Tribunal for Former Yugoslavia and the Dayton Peace Agreement: Peace Versus Justice?” International Peacekeeping 4 (2): 91-114.

Sharp, Dustin N. 2013a. "Beyond the Post-Conflict Checklist: Linking Peacebuilding and Transitional Justice Through the Lens of Critique." Chicago Journal of International Law 14 (1): 165-96.

United States Agency for International Development, 2015, Truth, Justice and Development https://blog.usaid.gov/2015/03/truth-justice-and-development/ Published 24 March 2015, Accessed 20 November 2015.

Sharp, Dustin N. 2013b. "Interrogating the Peripheries: the Preoccupations of Fourth Generation Transitional Justice". Harvard Human Rights Journal 26: 149-78.

Simić, Olivera, and Zala Volčič, ed. 2013. Transitional Justice and Civil Society in the Balkans. New York: Springer.

Sriram, Chandra Lekha. 2004. Confronting Past Human Rights Violations: Justice vs. Peace in Times of Transition. London: Frank Cass.

Sriram, Chandra Lekha. 2007. "Justice as Peace?: Liberal Peacebuilding and Strategies of Transitional Justice." Global Society 21 (4): 579-91.

Sriram, Chandra Lekha, and Suren Pillay (ed.). 2011. Peace Versus Justice?: the Dilemmas of Transitional Justice in Africa. Martlesham: James Currey.

Subotić, Jelena. 2014. "Legitimacy, Scope, and Conflicting Claims on the ICTY: in the Aftermath of Gotovina, Haradinaj and Perišić." Journal of Human Rights 13 (2): 170-85.

Tolbert, David. 2009. "International Criminal Law: Past and Future." University of Pennsylvania Journal of International Law 30 (4): 1281-94.

Waldorf, Lars. 2012. "Anticipating the Past: Transitional Justice and Socio-Economic Wrongs." Social Legal Studies 21 (2): 171-86. 